\title{
PENGEMBANGAN LEMBAR KERJA SISWA BERORIENTASI KETERAMPILAN PROSES DALAM PEMBELAJARAN SAINTIFIK TERHADAP HASIL BELAJAR SISWA PADA POKOK BAHASAN SISTEM PENCERNAAN MANUSIA
}

\author{
Has bullah \\ SMA N 1 Metro \\ E-mail: aambio39@yahoo.com
}

\begin{abstract}
The purpose of this study is to optimize the use of the Student Worksheet Worksheet student develops process-oriented skills, do Design Student Worksheet that can, measure student learning outcomes, do Design Student Worksheet on the subject of the Human Digestive System. For learners, learning must shift from "Notified" to "Actively seek out". The product specifications are expected in this study resulted in the Student Worksheet process-oriented skills that have the right procedures, adherence to learning the which includes initial, core and closing activity. Sheets Readability students a clear and operational notes the existence of multiple Interpretations by students, can measure cognitive leaming outcomes. In this study, using research and development is commonly known Research \& Development $(R \& D)$. Strategy to develop an educational product by Borg and Gall (1930) Referred to as research and development. Constructs validation by experts / specialists namely sheets Validation for experts in the form of an expert assessment of the various components and materials contained in LKS and observation Instrument Science Process Skills.
\end{abstract}

Kata kunci: le mbar kerja siswa, keterampilan proses sains (KPS)

Pemberlakuan Kurikulum tahun 2013 bisa digunakan sebagai langkah awal mengembalikan fungsi LKS seperti tujuan semula. Pembuatan LKS hanya sebagai pendamping dan mengembangkan kreativitas guru dalam menyusun LKS. LKS merupakan lembar kerja siswa untuk membantu siswa melakukan pengamatan atau percobaan yang memerlukan panduan dalam setiap langkahnya.

Bila LKS dibuat oleh guru sendiri dan tanpa bermaksud untuk mencari keuntungan, maka LKS benar-benar menjadi lembar kerja yang berfungsi memandu siswa dalam menyelesaikan tugasnya. LKS berfungsi sebagai pendamping buku teks pelajaran. Rangkuman materi pelajaran tidak diperlukan lagi dalam LKS, karena sudah ada dalam buku teks pelajaran.
LKS masih sangat diperlukan apabila pada buku teks atau paket belum berisi lembar kerja siswa. LKS penting untuk membimbing siswa melakukan serangkaian kegiatan pembelajaran. Sikap diperoleh melalui aktivitas" menerima, menjalankan, menghargai, menghayati, dan mengamalkan". Pengetahuan diperoleh melalui aktivitas" mengingat, memahami, menerapkan, menganalisis, mengevaluasi, mencipta. Keterampilan diperoleh melalui aktivitas“ mengamati, menanya, mencoba, menalar, menyaji, dan mencipta". Karaktersitik kompetensi beserta perbedaan lintasan perolehan turut serta mempengaruhi karakteristik standar proses. Untuk memperkuat pendekatan ilmiah (scientific), tematik terpadu (tematik antar mata pelajaran), dan 
tematik (dalam suatu mata pelajaran) perlu diterapkan pembelajaran berbasis penyingkapan/penelitian (discovery/ inquiry learning). Untuk mendorong kemampuan peserta didik untuk menghasilkan karya kontekstual, baik individual maupun kelompok maka sangat disarankan menggunakan pendekatan pembelajaran yang menghasilkan karya berbasis pemecahan masalah (project based learning). Guru memberikan kemudahan untuk proses ini, dengan mengembangkan suasana belajar yang memberi kesempatan peserta didik untuk menemukan, menerapkan ide-ide mereka sendiri, menjadi sadar dan secara sadar menggunakan strategi mereka sendiri untuk belajar. Guru mengembangkan kesempatan belajar kepada peserta didik untuk meniti anak tangga yang membawa peserta didik kepemahaman yang lebih tinggi, yang semula dilakukan dengan bantuan guru tetapi semakin lama semakin mandiri. Bagi peserta didik, pembelajaran harus bergeser dari "diberi tahu" menjadi "aktif mencari tahu".

Dengan menggunakan LKS mendorong dan menginspirasi peserta didik berpikir secara kritis, analistis, dan tepat dalam mengidentifikasi, memahami, memecahkan masalah, dan mengaplikasikan substansi atau materi pembelajaran. LKS juga dapat mengarahkan peserta didik mampu berpikir hipotetik dalam melihat perbedaan, kesamaan, dan tautan antara fakta, konsep, prinsip dan prosedur yang dialami siswa dalam proses pembelajaran.

Untuk memperoleh gambaran awal hasil belajar pada Kompetensi Dasar Menganalisis hubungan antara struktur jaringan penyusun organ pada sistem pencernaan dan mengaitkannya dengan nutrisi dan bioprosesnya sehingga dapat menjelaskan proses pencernaan serta gangguan fungsi yang mungkin terjadi pada sistem pencernaan manusia melalui studi literatur, pengamatan, percobaan, dan simulasi.

Melakukan uji kandungan zat makanan dari berbagai bahan makanan yang umum dikonsumsi, maka peneliti melakukan pra-survei terhadap hasil belajar biologi yang diperoleh dari ulangan harian siswa kelas XI SMA Negeri I Metro Tahun Pelajaran 2012/2013. Dengan melihat kategori ketuntasan belajar siswa yang telah ditetapkan oleh sekolah adalah 75, adapun hasil belajar ualangan harian siswa kelas XI SMA Negeri 1 Metro Tahun pelajaran 2012/2013 pada sistem pencernaan sebagai berikurt Katagori $\geq$ 75 , 69 siswa dari 188 prosentase ketuntasan 36,70\% sedangkan katagori $<75,119$ siswa dari 188 prosentasu ketuntasan 63,30\% .

Berdasarkan angka tersebut bahwa hasil belajar biologi siswa kelas XI 63,30\% tergolong kategori belum tuntas. Selain hasil belajar yang rendah, pengalaman selama ini menunjukkan, bahwa pada diri siswa SMA kelas XI pada sistem pencernaan mereka lebih banyak belajar dengan cara menghafal dan sekedar menerima informasi.

Banyak variabel yang mempengaruhi rendahnya hasil belajar siswa diantaranya siswa tidak menggunakan Lembar Kerja, siswa Siwa kurang terlibat aktif dalam proses pembelajaran, siwa tidak dapat menemukan fakta, konsep dan prinsip atau teori secara mandiri, siwa tidak dapat melakukan eksperimen uji makanan .

Tujuan penelitian ini adalah untuk mengoptimalkan penggunaan Lembar Kerja Siswa yaitu mengembangkan Lembar Kerja siswa yang berorientasi pada keterampilan proses, mendesain Lembar Kerja Siswa yang dapat, mengukur hasil belajar siswa, mendesain Lembar Kerja Siswa pada 
pokok bahasan Sistem Pencernaan Manusia.

Pentingnya penelitian dan pengembangan Lembar Kerja Siswa berorientasi keterampilan proses terhadap hasil belajar siswa pada pokok bahasan Sistem Pencernaan Manusia untuk dapat mingkatkan proses pembelajaran siswa berdasarkan pengalaman yang diperoleh selama proses belajar, siswa dapat membuat difinisi, konsep dan makna dari observasi, mengelompokan atau klasifikasi menafsikrkan atau interprestasi, meramalakan atau prediksi dalam proses pembelajaran.

Trianto (2009:222) menyatakan : Lembar Kerja Siswa dapat berupa panduan untuk latihan pengembangan aspek kognitif maupun panduan untuk mengembangkan semua aspek pembelajaran dalam bentuk panduan eksperimen atau demontrasi"

Trianto (2009:223) 'Komponenkompoenen LKS meliputi: judul, teori singkat tentang materi alat dan bahan prosedur kegiatan, data pengamatan serta pertanyaan dan kesimpulan untuk bahan diskusi"

Berdasarkan teori di atas dapat jelaskan bahwa lembar kerja siswa dapat digunakan sebagai sebagai panduan siswa untuk melakukan kegiatan pembelajaran secara mandiri untuk menemukan konsep yang dikaji dan dapat digunakan untuk mengembangkan pengetahuan dan keterampilan secara eksperimen/percobaan dan demontrasi. Dalam lembar kerja siswa (LKS) siswa akan mendapatkan uraian materi, tugas, dan latihan yang berkaitan dengan materi yang diberikan. Lembar Kerja Siswa digunakan untuk memepermudah siswa belajar secara mandiri memahami uraian materi, mengerjakan soal-soal yang di tanyakan dan dapat menkontruksi konsep yang dipelajari. Selain itu juga Lembar Kerja
Siswa merupakan salah satu sarana untuk membantu dan mempermudah dalam kegiatan belajar mengajar sehingga akan terbentuk interaksi yang efektif antara siswa dengan guru, sehingga dapat meningkatkan aktifitas siswa dalam peningkatan hasil belajar.

Karwono(2012:8), pembelajaran adalah terjemahan dari kata instructional, pembelajaran berpijak pada psikologi kognitif holistic yang selanjutnya diikuti pandangan konstruktif, humanistik dan seterusnya. Pembelajaran juga dipengaruhi oleh adanya perkembnagan teknologi, bahwa belajar dapat dipermudah melalui berbagai sumber belajar selain guru/dosen, sehingga mengubah peran guru dalam pembelajaran.

Trianto, 2010:144. Pengertian keterampilan proses merupakan keseluruhan keterampilan ilmiah yang terarah (baik kognitif maupun psikomotor) yang dapat digunakan untuk menemukan suatu konsep atau prinsip atau teori, untuk mengembangkan konsep yang telah ada sebelumnya, ataupun untuk melakukan penyangkalan terhadap suatu penemuan/ flasifikasi. Dengan kata lain keterampilan ini dapat digunakan sebagai wahana penemuan dan pengembangan konsep/prinsip/teori. Konsep/prinsip/teori yang telah ditemukan atau dikembangkan ini akan memantapkan pemahaman tentang keterampilan proses tersebut.

$$
\text { Trianto, 2010:144. }
$$

Keterampilan proses adalah keterampilan yang diperoleh dari latihan kemampuan mental, fisik, dan sosial yang mendasar sebagai pengerak kemampuan-kemampuan yang lebih tinggi. Kemampuan mendasar yang telah dikembangkan terlatih lamakelamaan akan menjadi suatu keterampilan. Dengan mengembangkan keterampilan-keterampilan proses siswa akan mampu menemukan dan 
mengembangkan sendiri fakta dan konsep serta menumbuhkan dan mengembangkan sikap nilai yang dituntut. Dengan demikian, keterampilan-keterampilan itu menjadi roda penggerak penemuan dan pengembangan fakta dan konsep serta pertumbuhan dan pengembangan sikap dan nilai.

Trianto,

(2010:

149),

Melatihkan keterampilan proses merupakan salah satu upaya yang penting untuk memperoleh keberhasilaan belajar siswa yang optimal. Materi pelajaran akan lebih mudah dipelajari, dipahami, dihayati dan diingat dalam waktu yang relatif lama bila siswa sendiri memperoleh pengalaman langsung dari peristiwa tersebut melalui pengamatan atau eksperimen. Selain itu, tujuan melatihkan keterampilan proses pada pembelajaran IPA diharapkan.

Permen No 66 tahun 2013 "pencapaian hasil belajar peserta didik mencakup: penilaian otentik, penilaian diri, penilaian berbasis portofolio, ulangan, ulangan harian, ulangan tengah semester, ulangan akhir semester, ujian tingkat kompetensi, ujian mutu tingkat kompetensi, ujian nasional, dan ujian sekolah/madrasah"

Sudjana (1989: 3)" bahwa hasil belajar siswa pada hakikatnya adalah perubahan tingkah laku yang telah terjadi melalui proses pembelajaran.Perubahan tingkah laku tersebut berupa kemampuan-kemapuan siswa setelah aktifitas belajar yang menjadi hasil perolehan belajar".

Sudjana (2005: 3) mengatakan bahwa hasil belajar itu berhubungan dengan tujuan instruksional dan pengalaman belajar yang dialami siswa.

Dengan demikian hasil belajar adalah perubahan yang terjadi pada individu setelah mengalami pembelajaran. Atas dasar itu maka lingkup sasaran penilaian mencakup tiga sasaran pokok, yakni (a)program pendidikan (b), proses belajar mengajar, dan (c)hasil hasil belajar.

\section{METODE}

Dalam penelitian ini menggunakan penelitian dan pengembangan yang umum dikenal Research \& Development ( R \& D). Strategi untuk mengmbangan suatu produk pendidikan oleh Borg \& Gall (1989) disebut sebagai penelitian dan pengembangan.

Sesuai dengan pengertian tersebut di atas, maka dalam penelitian ini mengunakan langkah-langkah penelitian dan pengembangan yang dikemukan oleh Sugiyono ( 2012: 409) sebagai berikut :

Proses pengembangan LKS berorintasi keterampilan proses terdiri dari 10 tahap, yaitu : potensi atau maslah, mengumpulkan infomasi, desain produk, validasi desain, revisi desain, uji coba, revisi produk, uji coba pemakaian, revisi produk, pembuatan produk masal.

Uji coba LKS berorintasi Keterampilan Proses ini di lakukan di SMA Negeri 1 Metro. Dipilih 1 kelas secara acak sebagai kelas untuk uji coba yaitu kelas XI IPA 5 dan Kelas XI IPA 6. Data yang diperoleh dari pengujian lapangan berupa kuantitatif yaitu data yang diperoleh dari penilaian oleh ahli/pakar 1 orang Dosen Biologi dari Universitas Muhammadiyah Metro, 1 orang pengawas dari Dinas Pendidkan Kota Metro dan 1 orang guru biologi senior, tes hasil belajar serta skor dari observasi Keterampilan proses Sains. Semua data yang diperoleh dianalisis melalui program SPSS 16.0.

Pada penelitian ini instrumen yang digunakan dalam mengumpulkan data adalah Instrumen non tes dan instrumen tes. Teknik analisa data penelitian ini dari instrumen lembar 
observasi dan instrument tes adapun data tersebut berasal dari Validasi Konstruk Lembar Kerja Siswa, Validasi Konstruk Observasi Keterampilan Proses Sains, Uji Validasi Soal Tes, Uji Reliabilitas Tes. Data yang diperoleh dari observasi Keterampilan Proses sains dan hasil belajar tes kognitif yang berupa tabulasi data dikakukan uji hipotesis penelitian dengan menggunakan uji. t-test rumus ini digunakan karena berkorelasi/berpasangan dengan $\mathrm{n} 1=\mathrm{n} 2$ untuk membandingkan sampel yang sama, seperti dikemukan oleh Sugiyono (2012:122)

Lembar Kerja siswa yang telah disusun divalidasi oleh validator. Selanjutnya dilakukan perbaikan LKS sesuai saran validator. Setiap validator memvalidasi seluruh isi LKS yang telah didesain. Hasil validasi Lembar Kerja Siswa ada 4 aspek yaitu materi, struktur/format, procedure ketrampilan proses, keterlaksnaan pembelajaran dan kebahasaan. Berikut garfik hasil validasi ahli terhadap LKS secara keseluruhan :

HASIL

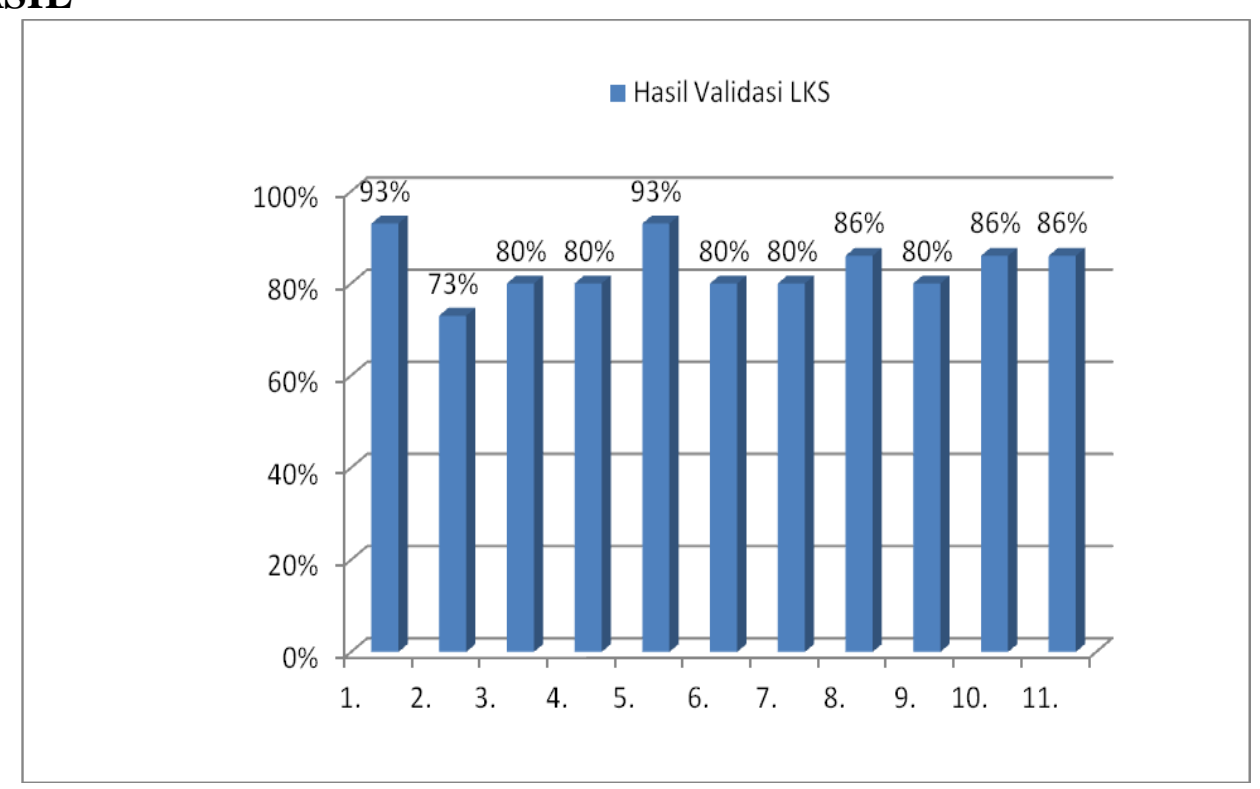

Gambar 1. Hasil Validasi LKS

Tabel 1. Saran dan Masukan Validator

\begin{tabular}{|l|l|l|}
\hline No & Validator & Saran \\
\hline 1 & Validator 1 & $\begin{array}{l}\text { Langkah kerja dan bahan diskusi diarahkan mendukung } \\
\text { Keterampilan Proses Sain. } \\
\text { Tujuan Pemebalajran disesuaikan dengan indikator } \\
\text { pencapaian }\end{array}$ \\
\hline 2 & Validator 2 & $\begin{array}{l}\text { Di masukan langkah kerja pada masing-masing pengujian } \\
\text { zat makanan yang akan di uji. } \\
\text { Sesuaikan Strutur Lembar Kerja Siswa }\end{array}$ \\
\hline 3 & Validator 3 & $\begin{array}{l}\text { Tata tulis harus dilengkapi sesuai dengan aturan } \\
\text { penulisan. }\end{array}$ \\
\hline
\end{tabular}




\begin{tabular}{|l|l|l|}
\hline & & Struktur materi dilengkapi. \\
\hline
\end{tabular}

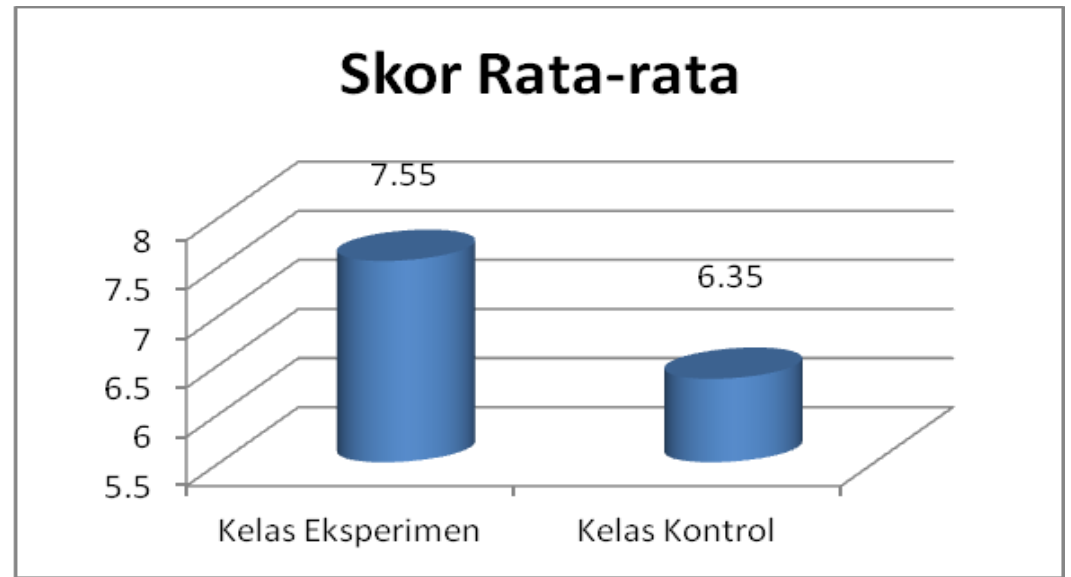

Gambar 2. Skor Rata-rata Kelas Eksperimen dan Kelas Kontrol

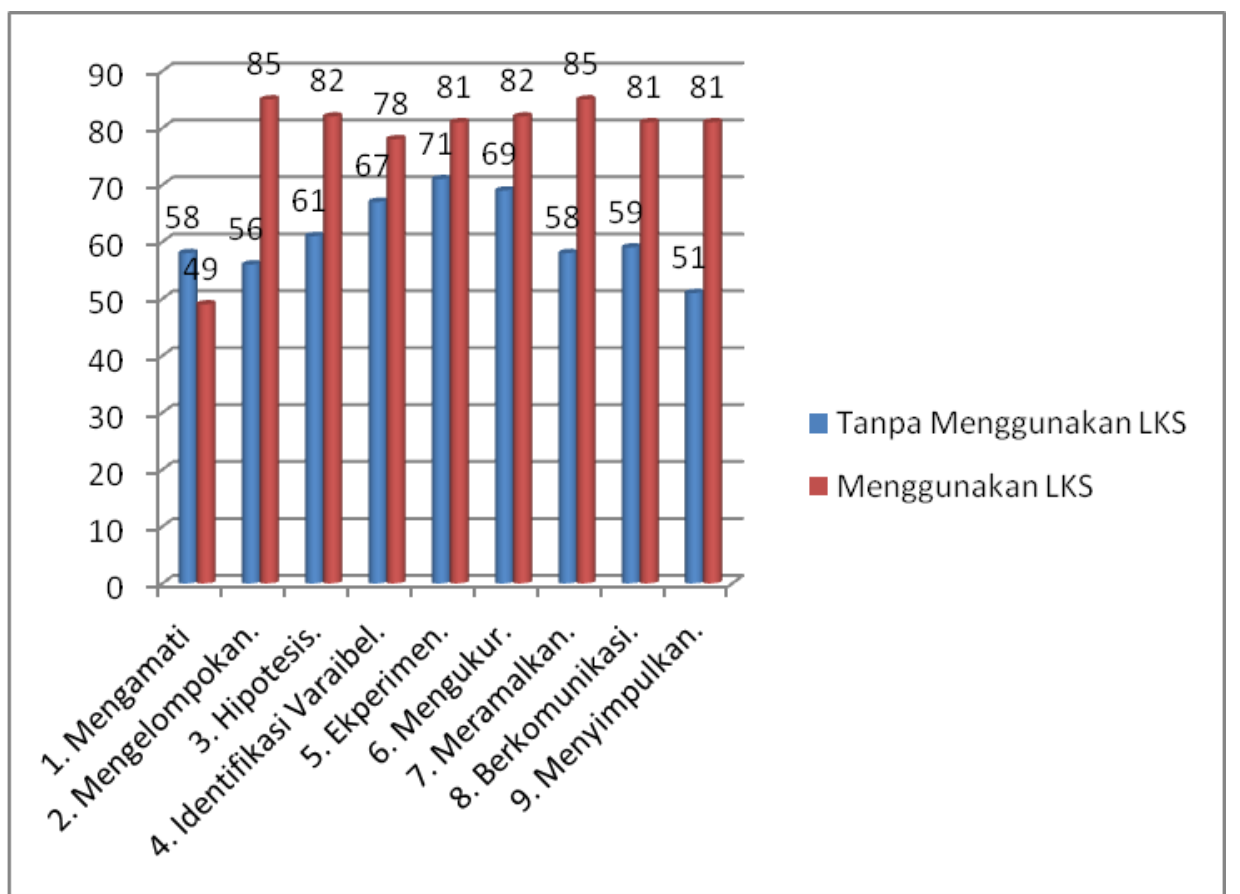

Gambar 3. Capaian Keterampilan Proses Sains

\section{PEMBAHASAN}

Berdasarkan Gambar 1. tersebut diperoleh data seluruh komponen di dalam LKS mempunyai nilai rata-rata di atas $70 \%$. Berdasarkan saran dan masukan Tabel 1. oleh validator maka desain awal direvisi dan dihasilkan desain Lembar Kerja Siswa berorintasi Keterampilan Proses Sains hasil revisi LKS tersebut diujicobakan pada siswa. Instrumen keterampilan proses dikembangakn menjadi indikatorindikator yang mengarahkan untuk meningkatkan keterampilan proses sain. Instrumen ini divalidasi oleh 2 orang guru biologi sebagai rekan sejawat sebelum digunakan untuk observasi di kelas agar memudahkan perhitungan menggunkan program SPSS 16.0. dengan menggunakan nilai reliabilitas alpha 0.934 maka untuk mengetahui validitas dengan ketentuan hasil item $<0.934$ sehingga dari hasil data tersebut semua item valid sedangkan untuk reliable jika uji intrumen yang positif dan > 0.6 
dikatakan reliable. Hasil uji nilai alpha 0.934. Jadi instrument tersebut reliabel.

Uji persyaratan varian dilakukan untuk mengetahui distribusi ( sebaran) data normal atau tidak. Begitupula uji homogenitas untuk mengetahui data homogen atau tidak jika data berditibusi normal dan homogen maka dilkukan uji t untuk mengatuhui perbedaan rata-rara kedua kelas tersebut menggunakan satistik Kolmogorov-Smirnov dengan Kriteria uji jika sig $>a(0.05)$ maka sebaran data berditribusi normal jika sig < $a$ maka data tidak berditribusi normal diamana nilai sig yang diperoleh adalah sebesar $0.176>0.05$ sehingga data tersebut berdistribusi normal. menggunakan Levene Statistic dengan kriteria uji jika sig > $a(0.05)$ maka varain populasi sama atau homogen dan jika sig < $a$ maka varian populasi tidak sama atau homogen diamana nilai sig $0.373>0.05$ varain populasi tersebut sama atau homogeny. Dari hasil perhitungan $\mathrm{t}$ hitung $>\mathrm{t}$ tabel, $8.731>1.685$ dimana dengan $\mathrm{dk}=\mathrm{n} 1+\mathrm{n} 2-2=20+20=38=$ 1.685 sig $5 \%$ sehingga dapat dinyatakan ada perbedaan rata-rata hasil pretes dan postes dalam kegiatan praktikum menggunakan Lembar Kerja Siswa.

Hasil perhitungan kelas kontrol bahwa $\mathrm{t}$ hitung $<\mathrm{t}$ tabel $=0.890<$ 1.685 dengan $\mathrm{dk}=\mathrm{n} 1+\mathrm{n} 2-2=20+20=38$ sig $5 \%=1.685$ sehingga dapat dinyatakan tidak ada perbedaan ratarata hasil pretes dan postes dalam kegiatan praktikum tanapa menggunakan Lembar Kerja Siswa.

Hasil perhitungan rata-rata kelas eksperimen dan kelas kontrol didapat $\mathrm{t}$ hitung $>\mathrm{t}$ tabel $=22.132>1.685$ dengan $\mathrm{dk}=\mathrm{n} 1+\mathrm{n} 2-2=20+20=38$ sig $5 \%=1.685$ sehingga dapat dinyatakan Ada perbedaan rata-rata hasil belajar siswa yang menggunakan Pengembangan Lembar Kerja Siswa
Berorintasi Keterampilan Proses Sains dalam Pembelajaran Saintifik yang menggunakan Lembar Kerja Siswa dan yang tidak menggunakan Lembar Kerja Sis wa. Hasil perhitungan terdapat pada lampiran 19. Begipula hasil akhir rata-rata kelas eksperiemn dan kontrol sangat jelas ada perbedaan yang siginfikan.

Berdasarkan Gambar 2, hasil validasi oleh validator menunjukan bahwa strukutur Format Lembar kerja Siswa memiliki rata-rata katagori baik untuk Prosedur Keterampilan Proses Sains mempunyai katagori baik, keterlaksanaan proses pembelajaran memperoleh katagori baik sedangkan bahasa mempunyai katagori sehingga dari hasil penilaian para validator Lembar Kerja ini dapat digunakan untuk uji coba kepada siawa.

Keterampilan Proses Sains (KPS) merupakan pendekatan pembelajaran yang berorientasi kepada proses Ilmu Penegtahuan Alam. Namun dalam tujuan dan pelaksanaann terdapat perbedaan. Dalam pembelajaran saintifik lebih menekankan pembelajaran aktifitas siswa lebih dominan melalui pengembangan Lembar Kerja Siswa berorintasi keterampilan proses siswa lebih aktif untuk mencari tahu hal ini dapat dilihat dari rata-rata hasil belajar siswa yang menggunakan Lembar Kerja Siswa berorintasi keterampilan proses dibandingkan dengan yang tidak menggunakan. Berikut hasi capaian Keterrampial Proses Sains kelas yang menggunakan Lembar Kerja siswa dan yang tidak menggunakan Lembar Kerja Siswa.

Bila dilihat dari skor rata kelas eksperimen dengan 9 item Keterampilan Proses Sains yang dicapai siswa maka Lembar Kerja Berorientasi Keteremapilan Proses Sains secara keseluruhan dapat 
meningkatkan hasil belajar siswa dan Keterampilan Proses Sains.

\section{KESIMPULAN}

Dalam pengembangan LKS dalam penelitian ini hanya 9 dasar pokok keterampilan proses yang digunakan dari Sembilan pokok tersebut di kembangkan menjadi 45 inidikator yang dapat diamati dalam kegaiatan praktikum siswa untuk meningaktkan hasil belajarnya. Dalam prosedur penelitian ini hanya melakukkan sampai tahap revisi desain dilanjutkan dengan uji coba dan mengahsilkan rata-rata hasil belajar yang berbeda secara signifikan antara kelas eksperimen dan kelas kontrol. Tahap uji coba pemakaian sampai dengan tahap produk masal tidak laksanakan karena keterbatasan waktu dan dana.

\section{SARAN}

Berdasarkan hasil pengembangan dalam peneltiani ini, maka penulis menyarankan: Sebaiknya LKS ini dibagikan kepada siswa 1 hari sebelum kegiatan pembelajaran dilakukan agar siswa dapat membaca dan memahami LKS ini. Penggunaan LKS ini disarakan dalam pembelajaranya menggunakan Team Teaching atau Lesson Study. Guru agar dapat menggunakan Lembar Kerja Siswa berorintasi Keterampilan Proses. Sehingga siswa diberikan kesempatan untuk menemukan pengalaman belajar yang akhrinya siswa dapat membangun konsep yang telah ditemukan berdasarkan pengalaman saat melakukan kegaiatan praktikum. Sekolah hendaknya memberikan fasilitas yang memdai agar setiap proses kegiatan pembelajaran bagi guru dan siswa dapat mengembangkan pengetahuannya.
DAFTAR PUSTAKA

Borg, W.R. \& Gall, M.D.1989. Educational Research, Longman, New York London.

Karwono. 2010. Belajar Dan Pembelajaran Serta Pemanfaatan Sumber Belajar. Ciputat: Cerdas Jaya.

Nuryani, Y. Rustaman. 2000. Strategi Belajar Mengajar Biologi. FPMIPA: UPI.

Sugiono. 2012. Metode Penelitian Kuantitatif Kualitatif dan $R \&$ $D$. Bandung: Alfabeta.

Trianto. 2010. Mendesain Model Pembelajaran InovatifProgresif. Jakarta : PT. Kencana.

Trianto. 2009. Mendesain Model Pembelajaran Inovatif Progresif. Jakarta: Kencana. 